would be removed and the public protected. In future, no one who has not had a thorough training may dispense or prescribe spectacles, but the Bill will not prevent, for example, a nurse testing the sight of school-children to ascertain whether they should go to an optician or an oculist, or testing a person's sight to ascertain whether he or she is suitable to carry out a particular task in industry.

\section{Spanish Electronics Bulletin}

THE recent development of the electronics industry in Spain is indicated by the publication of the first issue of the Boletin de información Electronica (1, No. 1 ; 1958. Pp. 62. Madrid : Instituto Nacional de Electronica, 1958. 25 pesetas). The contents are in Spanish and consist of two main articles; two technical contributions on the microwave band and an alarm and warning system for civil defence; a glossary and explanation of electronic terms, including klystron, spin, bias and radar; notes on new materials, instruments and circuits; and classified abstracts of articles in electronics journals. The two main articles are devoted to an introduction to the theory of information by A. Colino, director-general of Marconi Espanola, and to a description of the work and function of the Instituto Nacional de Electronica, respectively.

\section{Microtexts and Microrecording}

THE proceedings at a symposium held at Hatfield Technical College on January 14 have recently been published ("Microtexts and Microrecording"; pp. $27+$ 16 figures. County Technical Librarian, Hatfield Technical College, 1958. 4s.). They include a survey of microtexts by $H$. R. Verry ; the commercial use of microfilm by A. J. Brockbank; and handling, filing and indexing microtexts by Miss M. D. Gauntlett. A preface by the chairman, Councillor T. G. Mercer, explains that the symposium was arranged by the advisory committee appointed early in 1957 to assist in the establishment of a county technical library service, in which the Hertfordshire Special Libraries Group is actively co-operating. The advisory committee has recommended the installation of a microrecording unit at Hatfield Technical College as part of the proposed technical library service, which should be available to industry. Any firm interested in the possible application of microrecording or in the proposed technical library and information service is invited to approach $\mathrm{Mr}$. G. $\mathrm{H}$. Wright, the county technical librarian, at Hatfield Technical College. The value of Mr. Verry's survey and of Mr. Brockbank's account of the commercial use of microfilm is enhanced by the illustrations of readers and viewers and other equipment included in this report.

\section{Population Statistics for England and Wales}

The Civil Tables of the Registrar General's Statistical Review for England and Wales for 1956 which have just been published (The Registrar General's Statistical Review of England and Wales for the year 1956. Part 2 : Tables, Civil. Pp. $x+180$. London : H.M. Stationery Office, 1957. 7s. 6d. net) are in the main similar to previous issues. There is, however, one important addition to the fertility analysis. New tabulations make it possible to trace the fertility experience of a cohort of married women by exact duration of marriage, as well as the total exposure to risk in 1956. It has always been one of the difficulties in the analysis of fertility that it was not possible from the official statistics to relate the duration of specific fertility experience to the calendar year of marriage. Thus, women married between two and three years in 1956 may have been married either in 1953 or in 1954, and before this year it was impossible to allocate births in these years to the appropriate marriage cohort The new tabulation (Tables $N N$ to $P P$ ) makes such an allocation possible and thus enables the computations of the Royal Commission on Population on mean family size by exact duration of marriage to be continued. The new tabulations will be generally welcomed by demographers who are anxious to apply the techniques of cohort analysis to England and Wales.

\section{Industry and the Technical Colleges}

A REPOR'T of the regional conference on industry and the technical colleges, organized by the Southern Regional Council of the Federation of British Industries, in co-operation with the Southern Regional Council for Further Education and held at Windsor on October 15, has been published by the Federation (pp. 46. London: Federation of British Industries, 1958. 2s.). It includes the addresses of Mr. A. A. Part, Under-Secretary, Ministry of Education, on the background to the present position in technical education, and of $\mathrm{Mr}$. H. A. Collinson, managing director, Leicester, Lovell and Co., Ltd., on the needs of industry in technical education. There are also accounts of the ensuing discussions, including a panel discussion on industry's part in the administration of technical colleges, and Sir Henry Tizard's speech in summing up the conference; some figures illustrating the background to technical education are appended. Sir Henry did not attempt to sum up the discussion regarding the constitution of governing bodies of technical colleges, in which strong views were expressed as to the importance of effective industrial participation in the administration of such institutions. He stressed the need to raise the prestige of the technical colleges so that they attract more of our ablest and most intelligent young men, who at present enter the financial world instead of the technical side of industry. Mr. Collinson emphasized the need for better liaison between the technical colleges and the grammar schools, for more co-operation between industry and the technical colleges and for more attention to management studies: industry needs trained men at all levels but, above all, men with pass degrees and professional qualifications to form the hard core of practical management teams to secure the effective execution and application of production, development and research.

\section{Imperial College of Science and Technology}

THE fiftieth annual report of the Governing Body of the Imperial College of Science and Technology (Imperial College of Science and Technology (University of London). Fiftieth Annual Report, Jubilee Year 1956-1957. Pp. 91. London : Imperial College of Science and Technology, 1958) covers the year ended July 31, 1957. It includes Sir John Cockcroft's commemoration day address ; the address of welcome to Queen Elizabeth the Queen Mother at the formal opening of the new Roderic Hill Building for Aeronautics and Chemical Engineering on May 28; Lord Hailsham's speech at the Mansion House on May 27, and the Rector's reply ; the usual departmental lists of publications; and a list of special 